\title{
Rural-Urban Migrants Workers in China Evaluation Study of Labor Market Conditions in China
}

\author{
Gourida Siham
}

\begin{abstract}
According to the annual survey results projections by National Bureau of Statistics; the total migrant workers in 2012 amounted to $\mathbf{2 6 2 . 6 1}$ million, which refers to an increase of 9.83 million compared with the previous year with increase percentage by $3.9 \%$. This paper examines the working condition of rural migrant workers in china and the challenges faced by them. It describes the improvement and increase in the number of migrants, from around 30million in 1989 to 262.61 million in 2012. Using the data from various sources, this paper reviews briefly on the deprivation of various rights of ruralurban migrant form policy perspective in different aspects, such as employment, low wages, the problems of wage arrears, the lack of written contracts, the long working hours, the short weekly rest periods, the low social security coverage, the poor housing conditions, and the difficulties they face in accessing public services.
\end{abstract}

Index Terms-Rural migrants, China, working conditions, challenges.

\section{INTRODUCTION}

In 2011, about three quarters of the 3.6 billion urban dwellers on Earth lived in 25 countries, whose urban populations ranged from 31 million in Ukraine to 682 million in China. China, India and the United States accounted for 37 per cent of the world urban population. Most of the 25 countries with the largest urban populations are highly urbanized, but eight have levels of urbanization ranging from 28 per cent to 51 per cent and they include some of the most populous countries in the world: Bangladesh, China, India, Indonesia, Nigeria and Pakistan [1].

China has restricted internal movement in various ways. Official efforts to limit free migration between villages and cities began as early as 1952 with a series of measures designed to prevent individuals without special permission from moving to cities to take advantage of the generally higher living standards there.

The party decreased migration to cities during the 1960 s and 1970s for economic and political reasons. In the early stages of the Cultural Revolution (1966-76), large numbers of urban youths were "sent down" to the countryside for political and ideological reasons. Many relocated youths were eventually permitted to return to the cities, and by the mid-1980s most had done so.

The success of the agricultural reforms under Deng Xiaoping in the late 1970s and early 1980s dramatically increased the food supply in China's cities, making it possible

Manuscript received October 9, 2013; revised December 5, 2013.

Gourida Siham is with the Nanchang University- School of Economic and Management, China (e-mail: siham.hamadat@yahoo.com). for more people to come in from rural areas and survive without food ration cards. Because of the increased food supply, the authorities temporarily relaxed the enforcement of migration restrictions. This relaxation, however, was short-lived, and in May 1984 new measures strengthened residence regulations and reinstated official control over internal migration. Additionally, in March 1986 a draft revision of the 1957 migration regulations was presented to the Standing Committee of the Sixth National People's Congress calling for stricter population control policies.

Nonetheless, migration from rural areas to urban centers continued. The problem of too-rapid urbanization was exacerbated by the agricultural responsibility system, which forced a reallocation of labor and left many agricultural workers unemployed.

The central government attempted to control movement through the household registration system and promote development of small cities and towns, but within this system many people were still able to migrate primarily for employment or educational purposes. Leaving their place of official registration for days, months, or even years, unemployed agricultural workers found jobs in construction, housekeeping, or commune-run shops or restaurants. This temporary mobility was permitted by authorities because it simultaneously absorbed a large amount of surplus rural labor, improved the economies of rural areas, and satisfied urban requirements for service and other workers. The most significant aspect of the temporary migration, however, was that it was viewed as a possible initial step toward the development of small, rural-oriented urban centers that could bring employment and urban amenities to rural areas.

Although the temporary migration into the cities was seen as beneficial, controlling it was a serious concern of the central government. An April 1985 survey showed that the "floating" or non resident population in eight selected areas of Beijing was 662,000 , or 12.5 percent of the total population. The survey also showed that people entered or left Beijing 880,000 times a day. In an effort to control this activity, neighborhood committees and work units (danwei) were required to comply with municipal regulations issued in January 1986. These regulations stipulated that communities and work units keep records on visitors, that those staying in Beijing for up to three days must be registered, and that those planning to stay longer must obtain temporary residence permits from local police stations. Over the period between 1992 and 2006, the size of the rural migrant labour also more than doubled from 53 million to 115 million. Upward trends alike are also seen from other indicators of non-hukou population which have a substantial time span; The numbers and trends identified in the 1990s are also broadly consistentwith Yang (1996; 2004) [2], [3], Zhao (1998), [4], 
Chan (2001), [5], and Rozelle et al. (1999), [6].

The full story is riddled with special "Made in China" characteristics, particularly through China's unique system of discrimination and exclusion based on the hukou (household-registration) system. Unfortunately, these characteristics are often at best quite obscure to many outsider observers. Arguably, a Dickensian process with special Chinese features has produced one of the most exploitative systems of rural labor in modern times (Chan2008), [7].

Although a lot of factors affect the rural migrants' movement in China. They are therefore highly vulnerable to the effects of the global slowdown. The recession has decimated large numbers of migrants' jobs in many places in the world. In those other countries, foreign immigrants' jobs are mainly at risk; in China, it is the domestic migrants' jobs. China's hukou system enables local governments to treat internal migrants much like foreign migrants. The very size of China's huge migrant-labor population makes the scale of impoverishment that the slump has brought about staggering.

\section{RECENT History}

One of major concern in China is its growing "floating population", a large number of people moving from the countryside to the city, from underdeveloped economic areas to developed areas, and from the central and western regions to the eastern coastal region, as a result of fast-paced reform-era economic development and modern agricultural practices that have reduced the need for a large agricultural labor force. Although residency (Hukou) ${ }^{1}$ requirements have been relaxed to a degree, the floating population is not officially permitted to reside permanently in the receiving towns and cities.

The hukou system, directly and indirectly, continues to be a major barrier in preventing China's rural population from settling in the city and in maintaining the rural-urban apartheid. This problem has become more acute as rural migrant labor has turned more and more permanent (vis-a-vis seasonal) with an increasing proportion of women and children, as a comparative study of Chinese labor migration and Mexican migration to the USA has demonstrated (Roberts, 2007), [8].

More generally, two categories of migrants can thus be identified (Chan et al, 1999), [9]: a. Migration with "local" residency rights (bendi hukou) (hereafter, hukou migration). This is usually open only to a very select group (currently, the rich or the highly educated), and immediate family members of residents with local hukou (Chan and Buckingham, 2008), [10]; b. Migration without hukou residency rights (non-hukou migration).

As early as 1994, it was estimated that China had a surplus of approximately 200 million agricultural workers, and the number was expected to increase to 300 million in the early 21 st century and to expand even further into the long-term future. A household registration record officially identifies a

\footnotetext{
${ }^{1}$ A Hukourefers to the system of 'class system' residency permits which dates back to ancient China, where household registration is required by law in People's Republic of China (China) and Republic of China (Taiwan).
}

person as a resident of an area and includes identifying information such as name, parents, spouse, and date of birth.

It is believed that this slowdown in rural outflows was related to the sluggish performance of the urban economy, job competition from laid-off workers of urban state-owned enterprises (SOEs), increasingly protectionist policies used by local governments against recruitment of outsiders, and improvement in the rural economy, at least between 1996 and 1999 (Zhao, 1998, [4]; Cai and Chan, 2000), [11].

To many observers, what stands out in China's recent mobility change is not only the vast numbers of migrants reported here and there, but also that a great portion of them are, confusingly, permanent temporary population (non-hukou population), and enormous circulating labor moving back and forth between urban centers and villages every year (Fan and Taubmann, 1999, [12]; Liang and Ma, 2004), [13].

It was reported in 2005 that the floating population had increased from 70 million in 1993 to 140 million in 2003, thus exceeding 10 percent of the national population and accounting for 30 percent of all rural laborers.

According to the annual survey results projections by National Bureau of Statistics; the total migrant workers in 2012 amounted to 262.61 million, which refers to an increase of 9.83 million compared with the previous year with increase percentage by $3.9 \%$.

\section{WhO ARE THE RURAL MigRANT WORKERS}

\section{A. Most of the Migrants are Males, the Youth Migrants' Numbers Decline}

Migrant workers accounted about $66.4 \%$ of men, women accounted for $33.6 \%$; By age, migrant workers is given priority with young adults, 16 to 20 (4.9\%), 21-30 years old (31.9\%), 30-40years old $(22.5 \%), 41$ to 50 years old accounted for $25.6 \%, 15.1 \%$ migrant workers over the age of 50. Survey data show that migrant workers under the age of 40 percentage decline year by year, from $70 \%$ in 2008 to $59.3 \%$ by 2012 , peasant workers' average age is from 34 to 37.3 years.

TABLE I: THE AVERAge AgE of RuRAL MigRANT WORKERS

\begin{tabular}{|c|c|c|c|c|c|}
\hline Ages & 2008 & 2009 & 2010 & 2011 & 2012 \\
\hline $16-20$ & 10.7 & 8.5 & 6.5 & 6.3 & 4.9 \\
\hline $21-30$ & 35.3 & 35.8 & 35.9 & 32.7 & 31.9 \\
\hline $31-40$ & 24.0 & 23.6 & 23.5 & 22.7 & 22.5 \\
\hline $41-50$ & 18.6 & 19.9 & 21.2 & 24.0 & 25.6 \\
\hline Above 50 & 11.4 & 12.2 & 12.9 & 14.3 & 15.1 \\
\hline
\end{tabular}

\section{B. Most of Migrant Workers are Middle School Educated Level}

For the migrant workers about $14.3 \%$ were primary school educated, junior middle school level $(60.5 \%)$, junior high school level (13.3\%), technical secondary school level and above accounted for $10.4 \%$. Inter-provincial migrant workers' education level is higher than the local migrant 
workers, under the age of 30; young farmers got $2.4 \%$ increase in the proportion of high school education or above, higher than the other group of migrant workers.

The majority did not take part in any skill training programs; young migrant workers' participation in the agricultural technical training is low

TABLE II: EDUCATION LEVEL OF RURAL MiGRANTS

\begin{tabular}{|c|c|c|c|c|c|}
\hline & $\begin{array}{l}\text { Missing } \\
\text { migrant }\end{array}$ & Total & Local & Inter-province & $\begin{array}{l}\text { Youth } \\
\text { migrants } \\
\text { (under30) }\end{array}$ \\
\hline $\begin{array}{l}\text { Can read } \\
\text { and write a } \\
\text { little }\end{array}$ & 8.3 & 1.5 & 2.0 & 1.0 & 0.3 \\
\hline Primary & 33.8 & 14.3 & 18.4 & 10.5 & 5.5 \\
\hline $\begin{array}{l}\text { Junior } \\
\text { middle }\end{array}$ & 47.0 & 60.5 & 58.9 & 62.0 & 57.8 \\
\hline Junior high & 8.0 & 13.3 & 13.8 & 12.8 & 14.7 \\
\hline $\begin{array}{l}\text { technical seco } \\
\text { ndary school }\end{array}$ & 1.5 & 4.7 & 3.3 & 5.9 & 9.1 \\
\hline $\begin{array}{l}\text { University } \\
\text { or above }\end{array}$ & 1.4 & 5.7 & 3.6 & 7.8 & 12.6 \\
\hline
\end{tabular}

\section{BETWEEN RIGHTS AND RESPONSIBILITIES}

Studies on inter-provincial migration have argued that regional economic disparities have led to an increase in the number of people moving over long distances (Cai et al., 2001, [14]; Lin et al., 2004, [15] Fan 2005a; 2005b, [16]). Indeed, some believe that China experienced a continuing rise in inter-provincial disparities despite the extraordinary increase in geographic mobility of the population in that period. However, more careful work by Chan and Wang (2008) .has demonstrated that the previously observed widening regional economic disparities for 1995-2000 were based on incorrect de jure provincial population series, which overstated the interprovincial inequalities of 2000. They have shown that China's regional economic disparities, as measured by an inequality index (coefficient of variation), began to level off in the mid-1990s and have remained large but unchanged since then (see also Tsui, 2007), [17].

\section{A. Payment and Incomes Insecurity}

1) Migrant workers income slowed, eastern, central and western regions of migrant workers income convergence

By the end of 2012, the migrant worker per capita monthly income was 2290 yuan, an increase of 241 yuan, increased by $11.8 \%$. in the eastern region the migrant workers monthly income is 2286 yuan, an increase of 233 yuan, up by $11.4 \%$; In the central region the migrant workers monthly income is 2257 yuan, an increase of 251 yuan, up by $12.5 \%$; In the western region the migrant workers monthly income is 2226 yuan, an increase of 236 yuan, an increase of $11.8 \%$. In addition, in the overseas employment of migrant workers income is 5550 yuan per month.

2) In the large and medium cities of the migrant workers income level is relatively high

In the municipalities directly under the central government the migrant workers per capita monthly income of 2561 yuan, a year-on-year increase of 259 yuan. In the provincial capital cities the migrant workers month income 2277 yuan, an increase of 236 yuan. At the prefecture level and county-level city the migrant workers monthly income of 2240 yuan and 2204 yuan respectively, 229 yuan and 222 yuan respectively. Migrant workers in big cities income levels increase higher than the level of small and medium-sized cities.

\begin{tabular}{|c|c|c|c|c|c|}
\hline & & & & \multicolumn{2}{|c|}{ Unit Yuan/Person } \\
\hline & 2008 & 2009 & 2010 & 2011 & 2012 \\
\hline Nationwide & 1340 & 1417 & 1690 & 2049 & 2290 \\
\hline East & 1352 & 1422 & 1696 & 2053 & 2286 \\
\hline Middle & 1275 & 1350 & 1632 & 2006 & 2257 \\
\hline West & 1273 & 1378 & 1643 & 1990 & 2226 \\
\hline
\end{tabular}

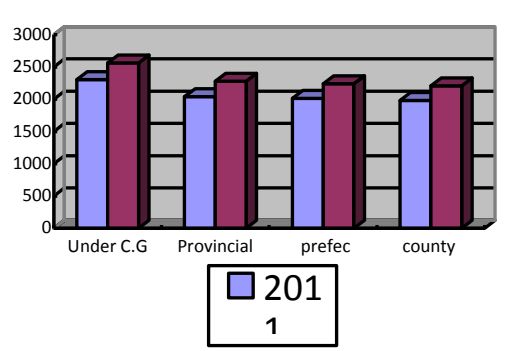

Fig. 1. Different rural areas monthly income level (yuan/person).

\section{3) Income level difference of different industries, accommodation catering and service industry average income level is low}

Look to the migrant worker in the main industry, higher income level is the postal service of storage and transportation construction, the per capita monthly income is about 2735 yuan and 2654 yuan respectively; With lower incomes were in services, accommodation catering and manufacturing, average monthly income of 2058 yuan, 2100 yuan and 2130 yuan respectively.

\section{B. Employment and Job Insecurity}

- Default salary situation continued to improve

Inter-provincial employed migrant workers, the unpaid wages accounted for $0.5 \%$, decreased by $0.3 \%$ compared with the previous year. Construction of peasant workers unpaid wages accounted for $1.5 \%$, falling by $0.4 \%$ over the previous year. From the survey data in recent years, the unpaid wages decline year by year.

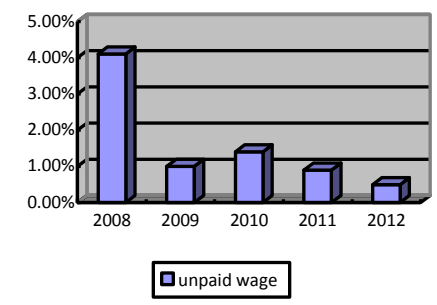

Fig. 2. Inter-provincial migrant workers unpaid wages.

- Improve the migrant workers sign labor contract status is not obvious

Inter-provincial employed migrant workers sign labor 
contract with the employer or unit accounted for $43.9 \%$, essentially flat with the previous year, seen from the survey data in recent years, sign labor contract with unit of migrant worker and the employer or the proportion of change is not big, no obvious improvement. Divisions, in 2012 did not sign labor contracts with migrant workers, the proportion of the construction industry is $75.1 \%$, up by $1.5 \%$ over the previous year; Manufacturing was $48.8 \%$, down by $48.8 \%$ over the previous year; Service industry is $60.8 \%$, falling by $0.6 \%$ over the previous year; Accommodation catering industry was $62.4 \%$, down by $62.4 \%$ over the previous year; Wholesale and retail at $59.9 \%$, down by $59.9 \%$ over the previous year.

\section{Living Conditions}

The percentage of migrant workers in form of employment, living in the dorms account for $32.3 \%$, and about $10.4 \%$ Living in the construction site or barrack. 6.1\% Living in the sites of production and business operation, with others who rent housing accounted for $19.7 \%$, independent of the rental housing accounted for $13.5 \%, 13.8 \%$ of the migrant worker live outside the villages and towns moving every day. For the migrant worker living conditions have changed in recent years, rising of the migrants who rent houses together with others, out of proportion with others only rent housing,

TABLE IV: INTER-PROVINCIAL MIGRANTS LIVING CONDITIONS

\begin{tabular}{|c|c|c|c|c|c|}
\hline & 2008 & 2009 & 2010 & 2011 & 2012 \\
\hline Dormitory & 35.1 & 33.9 & 33.8 & 32.4 & 32.3 \\
\hline Site barrack & 10.0 & 10.3 & 10.7 & 10.2 & 10.4 \\
\hline $\begin{array}{l}\text { The sites of } \\
\text { production and } \\
\text { business } \\
\text { operation }\end{array}$ & 6.8 & 7.6 & 7.5 & 5.9 & 6.1 \\
\hline $\begin{array}{l}\text { Sharing with } \\
\text { others }\end{array}$ & 16.7 & 17.5 & 18.0 & 19.3 & 19.7 \\
\hline $\begin{array}{l}\text { Independent rental } \\
\text { housing }\end{array}$ & 18.8 & 17.1 & 16.0 & 14.3 & 13.5 \\
\hline Others & 3.2 & 3.5 & 3.5 & 4.0 & 3.6 \\
\hline
\end{tabular}

- Forty percent of migrant employers don't provide accommodation and no housing subsidies

About $49.5 \%$ of the migrant workers were provided free accommodation by the employer; $9.2 \%$ of migrant workers cases, the employer does not provide accommodation, but have the housing subsidies; $41.3 \%$ of migrant workers the employer does not provide accommodation and no housing subsidies. Compared with the previous year, the proportion of free accommodation provided by the employer or the unit has fallen by $0.4 \%$; without provide accommodation, but have increased the proportion of housing subsidies by $0.4 \%$.

\section{Social Security}

- The migrant worker participates in social insurance level has increased, but overall is still low

The employer of migrant workers pays endowment insurance, industrial injury insurance, medical insurance, unemployment insurance and maternity insurance are respectively $14.3 \%, 24 \%, 14.3 \%, 8.4 \%$ and $6.1 \%$, increased by $0.4,0.4,0.2,0.4$ and $0.5 \%$ than the previous year. From the survey data of nearly five years, migrant worker endowment insurance, medical insurance, unemployment insurance and maternity insurance rate increase by about $4 \%$, and the "five risks" relatively high rates of industrial injury insurance is not obviously improved.

TABLE V: THE PROPORTION OF MigRANT WORKER WHO ARE COVERED BY SOCIAL SECURITY

\begin{tabular}{l|l|l|l|l|l}
\hline & 2008 & 2009 & 2010 & 2011 & 2012 \\
\hline $\begin{array}{l}\text { endowment } \\
\text { insurance } \\
\text { accident insuranc } \\
\mathrm{e}\end{array}$ & 9.8 & 7.6 & 9.5 & 13.9 & 14.3 \\
$\begin{array}{l}\text { medical insurance } \\
\text { unemployment } \\
\text { insurance } \\
\text { maternity } \\
\text { insurance }\end{array}$ & 13.1 & 12.2 & 14.3 & 16.7 & 16.9 \\
\hline
\end{tabular}

TABLE VI: DIFFERENT MIGRANT WORKERS SOCIAL SECURITY LEVEL WITH DIFFERENT INDUSTRIES SECTORS

\begin{tabular}{|c|c|c|c|c|c|}
\hline industry & $\begin{array}{l}\text { endowment } \\
\text { insurance }\end{array}$ & $\begin{array}{l}\text { accident i } \\
\text { nsurance }\end{array}$ & $\begin{array}{l}\text { imedical i } \\
\text { nsurance }\end{array}$ & $\begin{array}{l}\text { unemployment } \\
\text { insurance }\end{array}$ & $\begin{array}{l}\text { maternity } \\
\text { insurance }\end{array}$ \\
\hline manufacturing & 15.2 & $\begin{array}{l}28 . \\
9\end{array}$ & $\begin{array}{l}18 . \\
5\end{array}$ & 8.1 & 5.3 \\
\hline construction & 3.8 & $\begin{array}{l}14 . \\
0\end{array}$ & 6.0 & 2.2 & 1.5 \\
\hline $\begin{array}{l}\text { Transportation, } \\
\text { warehousing }\end{array}$ & 24 & 30. & 26. & 15 & 112 \\
\hline $\begin{array}{ll}\text { and } & \text { postal } \\
\text { service } & \end{array}$ & 24.1 & 6 & 7 & 15.0 & 11.5 \\
\hline $\begin{array}{l}\text { Wholesale and } \\
\text { Retail Trade }\end{array}$ & 14.3 & $\begin{array}{l}17 . \\
1\end{array}$ & $\begin{array}{l}15 . \\
7\end{array}$ & 9.3 & 7.2 \\
\hline $\begin{array}{l}\text { Hotels and } \\
\text { Catering } \\
\text { Service }\end{array}$ & 7.0 & $\begin{array}{l}12 . \\
4\end{array}$ & 8.8 & 3.9 & 2.9 \\
\hline $\begin{array}{l}\text { Resident } \\
\text { Services } \\
\text { \&Other } \\
\text { Services }\end{array}$ & 12.1 & $\begin{array}{l}16 . \\
9\end{array}$ & $\begin{array}{l}13 . \\
3\end{array}$ & 6.9 & 5.2 \\
\hline
\end{tabular}

Different parts of the migrant workers social security condition still has certain gap

The central region in 2012 the insurance rate got an increase slightly above the eastern and western areas.

- Different migrant workers social security level with different industries sectors

From migrant worker in the main industry, manufacturing, transportation, storage and the postal service, the insurance of wholesale and retail and service industry is relatively good, and the construction industry, accommodation catering industry of migrant workers, the proportion of the employer who pays the insurance for its obviously lower than other 
industries. Increasing the proportion in 2012 in manufacturing various insurances were faster than other industries.

"The eastern region including Beijing, tianjin, hebei, liaoning, Shanghai, jiangsu, zhejiang, fujian, shandong, guangdong, hainan 11 provinces (municipalities); The central region including shanxi, jilin, heilongjiang, anhui, jiangxi, henan, hubei, hunan eight provinces; In the western region including Inner Mongolia, guangxi, chongqing, sichuan, guizhou, yunnan, Tibet, shaanxi, gansu, qinghai, ningxia, xinjiang's 12 provinces (municipalities and autonomous regions). Regional distribution of employment of migrant workers, in addition to the eastern, central and western areas, and $0.3 \%$ of migrant worker in Hong Kong, Macao and Taiwan area and foreign industry."

\section{CONCLUSION}

A majority of people in China probably agree that the household registration system is archaic and unfair and that rural hukou holders working in the cities should be given greater access to schooling, social and medical welfare benefits.

However, there is also considerable resistance from urban residents to relaxation of restrictions. Urban governments often do not have the financial resources to expand provision of social services to include all migrant workers and their families. There is also resistance from the police to wholesale hukou reform, at least until an alternative system of national identity cards can be put in place that can ensure effective surveillance and tracking of criminals.

At present, hukou reform has been limited to piecemeal reform at the local level, with individual regions relaxing restrictions for certain rural migrant workers, in most cases those from the same province and those who have already made a demonstrable contribution to the local economy. That approach seems destined to continue for the foreseeable future.

We summarize with some recommendations of the central government in Beijing which develops the political to push through hukou reform; China Labor Bulletin recommends it takes the following action:

Decouple the link between the hukou and the provision of social services. All children living in the same city should have the same rights to health and education services, social advancement and social participation.

Make urban governments solely responsible for welfare provision in the cities. China's cities are the clear beneficiaries of rural-urban migration and should no longer pass the costs of welfare provision on to poorer rural governments.

Make greater efforts towards urban integration. Social acceptance by the resident urban population is the key to the smooth progress of hukou reform.

Invest more in rural education and healthcare. As well as building new schools and health clinics, better qualified teachers and medical staff should be recruited. Salaries should be increased and paid on time.

\section{REFERENCES}

[1] United Nations, World Population Prospects, Department of Economic and Social Affairs, 2011-2012.

[2] Y. Y. Yang, "Temporary residents in China: causes and characteristics," Chinese Environment and Development, vol. 7, no. 1-2, pp. 103-117, 1996.

[3] New features of population migration in the 1990s in China, Nanfang renkou (Southern Population), no. 75, pp. 13-20, 2004.

[4] S. K. Zhao, "The mobility of rural migrants: new stage and new issues," Analysis and Forecast of the Social Situation of China, State Council, Development Research Center, Beijing: Shehui wenxian chubanche, pp. 76-89, 1998.

[5] K. W. Chan, "Recent migration in China: patterns, trends, and policie," Asian Perspectives, vol. 25, no. 4, pp. 127-155, 2001.

[6] R. Scott, L. Guo, M. G. Shen, A. Hughart, and J. Giles, "Leaving China's farms: survey results of new paths and remaining hurdles to rural migration," The China Quarterly, no. 158, pp. 367-393, 1999.

[7] K. W. Chan, "Internal labor migration in China: trends, geographical distribution and policies," University of Washington, 2008.

[8] K. D. Roberts, "The changing profile of Chinese labour migration?" in Transition and Challenge: China's Population at the Beginning of the 21 Century, Z. W. Zhao and F. Guo, (eds.), New York: Oxford University Press, 2007.

[9] K. W. Chan and L. Zhang, "The hukou system and rural-urban migration: processes and changes," The China Quarterly, no. 160, pp. 818-855, 1999.

[10] K. W. Chan and W. Buckingham, "Is China abolishing the hukou system?" The China Quarterly, no. 195, pp. 582-606, 2008.

[11] C. Fang and K. W. Chan, "The political economy of urban protectionist employment policies in China," Working Paper Series No.2, Chinese Academy of Social Sciences, Institute of Population Studies, 2000.

[12] J. Fan and W. Taubmann, "Migrant enclaves in Chinese large cities," paper presented at the International Conference on Urban Development in China, Zhongshan, China, December 6-9, 1999.

[13] L. Zai and Z. D. Ma, "China's floating population: new evidence from the 2000 census," Population Development Review, vol. 30, no. 3, pp. 467-488, 2004.

[14] C. Fang, D. W. Wang, and Y. Du, "Laodongli shichang niuqu duiquyu caju de yingxing (Impact of labour market distortion on regional disparities)," Zhongguo shehui kexue, no. 2, pp. 4-14, 2001.

[15] J. Lin, G. W. Wang, and Y. H. Zhao, "Regional inequality and labor transfers in China," Economic Development and Cultural Change, vol. 52, pp. 587-603, 2004.

[16] C. Fan, "Modelling interprovincial migration in China, 1985-2000," Eurasian Geography and Economics, vol. 46, no. 3, pp. 165-184, 2005.

[17] K.-Y. Tsui, "Forces shaping China's interprovincial inequality," Review of Income and Wealth, vol. 53, no. 1, pp. 60-92, 2007.

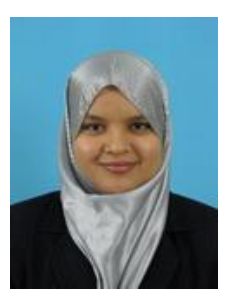

Siham Gourida was born on July 22, 1987. She is from Algeria. She got her MBA degree in 2011 from Nanchang University. Now she is working on her Ph.D. to get it by July 2014 in Nanchang UniversitySchool of Economic and Management. Her master degree was about the employee' motivation and job satisfaction for the labors those who are from different cultural background. And now her study is focusing on the rural to urban labor mobility in china and Arab world. During her internship in MBA program she worked as international sales manager on RIBO industry and Trade Company. And she also Work with Nanchang University and Chinese ministry of commerce as interpreter in Seminars about Chinese culture and economy. Now she is teaching college English listening in Nanchang University .school of software. 